\title{
Agronomical performance of 'Piemonte' mandarin grafted on several rootstocks in the Brazilian Coastal Tablelands
}

\author{
Hélio Wilson Lemos de Carvalho(1), Carlos Roberto Martins ${ }^{(2)}$, Adenir Vieira Teodoro(1), \\ Walter dos Santos Soares Filho ${ }^{(3)}$ and Orlando Sampaio Passos ${ }^{(3)}$
}

\begin{abstract}
(1)Embrapa Tabuleiros Costeiros, AvenidaBeiraMar, no3.250, Jardins, CEP49025-480Aracaju, SE, Brazil.E-mail:helio.carvalho@embrapa.br, adenir.teodoro@embrapa.br (2)Embrapa Clima Temperado, Rodovia BR-392, KM 78, $9^{\circ}$ Distrito, Monte Bonito, Caixa Postal 403, CEP 96010-971 Pelotas, RS, Brazil. E-mail: carlos.r.martins@embrapa.br ${ }^{(3)}$ Embrapa Mandioca e Fruticultura, Rua Embrapa, s/no, Caixa Postal 007, CEP 44380-000 Cruz das Almas, BA, Brazil. E-mail: walter.soares@embrapa.br, orlando.passos@embrapa.br
\end{abstract}

\begin{abstract}
The objective of this work was to evaluate the agronomical performance of 'Piemonte' mandarin grafted on 11 rootstocks grown under the edaphoclimatic conditions of the Coastal Tablelands, in the state of Sergipe, Brazil. The following combined agronomical parameters were evaluated: vegetative growth, abundance of phytophagous mites, plant yield, drought tolerance, and physicochemical quality of fruit. 'Piemonte' mandarin had the best productive performance when grafted on 'Santa Cruz Rangpur' lime, 'Red Rough' lemon, 'Sunki Tropical' mandarin, and 'Riverside' citrandarin, and it was more tolerant to drought when grafted on 'Santa Cruz Rangpur' lime and on the LVK x LCR-010 hybrid. Rootstocks did not affect pest population levels. 'Piemonte' mandarin grafted on 'Santa Cruz Rangpur' lime and 'Red Rough' lemon produced lower-quality fruit. The 'Indio' and 'San Diego' citrandarins, the HTR-051 hybrid, and 'Swingle' citrumelo have potential for high-density plantings. 'Sunki Tropical' mandarin and 'Riverside' citrandarin are a good option for the diversification of rootstocks in orchards in the agroecosystem of the Brazilian Coastal Tablelands.
\end{abstract}

Index terms: Citrus, cohesive soils, fruit quality, planting density, phytophagous mites, yield efficiency.

\section{Desempenho agronômico da tangerineira 'Piemonte' enxertada em diversos porta-enxertos nos Tabuleiros Costeiros}

\begin{abstract}
Resumo - O objetivo deste trabalho foi avaliar o desempenho agronômico da tangerineira 'Piemonte' enxertada em 11 porta-enxertos cultivados nas condições edafoclimáticas dos Tabuleiros Costeiros, no Estado de Sergipe. Os seguintes parâmetros agronômicos combinados foram avaliados: crescimento vegetativo, abundância de ácaros fitófagos, produção, tolerância à seca e qualidade físico-química de frutos. A tangerineira 'Piemonte' apresentou o melhor desempenho produtivo quando enxertada nos limoeiros 'Cravo Santa Cruz' e 'Rugoso Vermelho', na tangerineira 'Sunki Tropical' e no citrandarin 'Riverside', e se tornou mais tolerante ao deficit hídrico quando enxertada no limoeiro 'Cravo Santa Cruz' e no híbrido LVK x LCR-010. Os porta-enxertos não influenciaram o nível populacional de pragas. A tangerineira 'Piemonte' enxertada nos limoeiros 'Cravo Santa Cruz' e 'Rugoso Vermelho' produziu frutos de qualidade inferior. Os citrandarins 'Indio' e 'San Diego', o híbrido HTR-051 e o citrumelo 'Swingle' apresentam potencial para plantios adensados. A tangerineira 'Sunki Tropical' e o citrandarin 'Riverside' são uma boa opção para a diversificação de porta-enxertos em pomares no agroecossistema dos Tabuleiros Costeiros.
\end{abstract}

Termos para indexação: Citrus, solos coesos, qualidade de frutos, densidade de plantio, ácaros fitófagos, eficiência produtiva.

\section{Introduction}

The cultivation and consumption of mandarins and their hybrids is growing worldwide (FAO, 2015). The rising consumption of fresh mandarins is owed to its easy peeling and splitting, combined with its nutraceutical properties and flavor (Wu et al., 2014; Zhang et al., 2014). China is the world's leading producer of mandarins, with approximately 15 million tons, most of which for the domestic market. Brazil ranks third, with a production of around 1 million tons of fruit (FAO, 2015). Brazilian mandarin orchards are predominantly found in the Southeastern and Southern regions, and the states of São Paulo, Minas Gerais, Paraná, and Rio Grande do Sul are the main producers. 
Overall, mandarins grown in Brazil are grafted on 'Rangpur' lime (Citrus limonia Osbeck) (Silva et al., 2013), which is the main rootstock cultivar being used across the Northeastern region. In the state of Sergipe, 'Rough' lemon ( $C$. jambhiri Lush.) is also used as a rootstock, but to a lesser extent than 'Rangpur' lime. In the Brazilian Coastal Tablelands, which lie along the coastline and are characterized by cohesive soils with low water availability during part of the year, new rootstock and scion cultivars have been investigated in order to promote varietal diversification (Moraes Filho et al., 2011; Martins et al., 2014). Among these cultivars, 'Piemonte' mandarin is a hybrid that has been highlighted for its potential to produce high-quality fresh fruits in Northeastern Brazil (Passos et al., 2013). This mandarin results from the crossing between 'Clementine' mandarin and 'Murcott' tangor, and it is characterized by short to medium size, late fruit maturation, and orange-red colored pulp, with seeds (Almeida \& Passos, 2011).

The rootstock plays a key role - in combination with the scion cultivar - on several characteristics of the plants, such as growth, plant and fruit development, maturation, precocity, yield, fruit quality, and tolerance to drought, pests, and diseases. Under the same conditions, some rootstocks excel in certain aspects (Schäfer et al., 2001); therefore, adaptation and proper selection studies are pivotal for indicating cultivars for specific regions (Auler et al., 2008). The need to diversify rootstocks in the Brazilian citrus industry and to increase production efficiency through higher planting densities has brought attention to dwarfing rootstocks, which induce small scion size (Bastos et al., 2014). This diversification is also required in order to obtain higher production and fruit quality, besides the possibility of extending the harvest period (Silva et al., 2013).

Regarding phytotechnical problems, citrus orchards in the Northeastern region of Brazil are attacked by a variety of pests, including: the citrus rust mite, Phyllocoptruta oleivora (Acari: Eriophyidae); the Texas citrus mite, Eutetranychus banksi; and the spider mite, Tetranychus mexicanus (Acari: Tetranychidae) (Moraes \& Flechtmann, 2008; Mendonça \& Silva, 2009; Teodoro et al., 2014). This shows the importance of evaluating whether citrus rootstocks affect pest populations. For instance, lower population levels of the leprosis mite Brevipalpus phoenicis (Acari: Tenuipalpidae) were found on 'Pêra' sweet orange grafted on 'Sunki' mandarin, when compared with 'Cleopatra' mandarin
(C. reshni hort. ex Tanaka) and 'Rangpur' lime (Andrade et al., 2013).

The objective of this work was to evaluate the agronomical performance of 'Piemonte' mandarin grafted on 11 rootstocks grown under the edaphoclimatic conditions of the Coastal Tablelands, in the state of Sergipe, Brazil.

\section{Materials and Methods}

The experiment was implemented in 2008 in a Haplic Acrisol, according to $\mathrm{WRB} / \mathrm{FAO}$, at the experimental station of Embrapa Tabuleiros Costeiros, located in the municipality of Umbaúba, in the Coastal Tablelands of

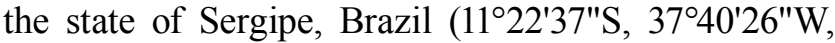
at $109 \mathrm{~m}$ above sea level). The Coastal Tablelands run along the Brazilian coastline and are characterized by cohesive soils, with low water availability during part of the year and low organic matter (Cintra et al., 2009; Martins et al., 2016). The climate, according to Köppen's classification, is As - rainy tropical with a dry summer (Prudente et al., 2004). During the experiment, the average annual temperature was $24.6^{\circ} \mathrm{C}$, relative humidity was $83 \%$, and rainfall was $1,315 \mathrm{~mm}$, according to data collected from the local meteorological station. Plants were spaced at 5.0x3.0 m (666 trees per hectare) and were conventionally managed without irrigation, except in the driest months, from December to March 2008-2010, when each plant received irrigation with $3 \mathrm{~L}$ of water weekly. Management practices included fertilization, control of pests, diseases, and weeds, as well as pruning, after harvest.

The experiment consisted of 'Piemonte' mandarin grafted on: 'Santa Cruz Rangpur' lime; common 'Rangpur' lime; 'Red Rough' lemon; 'Orlando' tangelo (C. paradisi Macfad. x C. tangerina Tanaka); 'Sunki Tropical' (C. sunki Hort. ex Tanaka) mandarin; 'Swingle' citrumelo [C. paradisi x Poncirus trifoliata (L.) Raf.]; 'Indio', 'Riverside', and 'San Diego' citrandarins (C. sunki x P. trifoliata); and the HTR-051 (P. trifoliata zygotic hybrid) and LVK x LCR-010 (C. volkameriana Pasq. x C. limonia) hybrids, generated in the citrus breeding program of Embrapa Mandioca e Fruticultura. The experiment was conducted in a randomized complete block design, with four replicates and two trees per plot.

Evaluations were conducted for four subsequent harvests, from 2011 to 2014, by measuring, in May, plant height, trunk diameters of rootstock (DA) and scion

Pesq. agropec. bras., Brasília, v.51, n.11, p.1830-1838, nov. 2016 DOI: 10.1590/S0100-204X2016001100005 
(DB), relationship between the trunk diameter below and above the grafting line (RDBDA), canopy volume, drought tolerance, annual yield, cumulative yield, yield efficiency, and fruit physicochemical quality.

Plant height was measured from the base of the trunk, close to the soil, up to the top of the plant using a ruler. Canopy volume (CV) was calculated with the equation $\mathrm{CV}=(\pi / 6) \times \mathrm{PH} \times \mathrm{DR} \times \mathrm{DP}$, in which $\mathrm{CV}$ is the canopy volume $\left(\mathrm{m}^{3}\right), \mathrm{PH}$ is the plant height $(\mathrm{m}), \mathrm{DR}$ is the canopy diameter along the row, and DP is the canopy diameter in the direction perpendicular to the row (Cantuarias-Avilés et al., 2011). DB and DA were measured using a caliper rule placed $10 \mathrm{~cm}$ above and below the grafting point; they were used to obtain the RDBDA by the quotient between DB/DA. Drought tolerance was visually assessed in the canopy of each tree during the driest months, from December to April 2011, 2012, 2013, and 2014, and was classified as adapted from Stuchi et al. (2000): 1, susceptible to drought, with wilt, yellowing, and leaf drop; 2, moderate drought tolerance, showing intermediate wilt, yellowing, and no leaf drop; and 3, tolerant to drought, with no visual symptoms.

Fruit from all plants were counted and weighed in each harvest. With the data of yield and planting density, productivity for each cultivar was estimated in $\mathrm{Mg} \mathrm{ha}^{-1}$. Cumulative yield comprised the period from 2011 to 2014. Yield efficiency was estimated by the quotient between the production of fruits per plant (kilogram per tree) and the canopy volume (square meter per tree), according to Auler et al. (2008).

Fruit quality was evaluated in the 2014 and 2015 harvests by collecting six fruits per plant. The height, diameter, and shell thickness $(\mathrm{mm})$ of fruits were measured with a digital caliper. For this, fruits were weighed and the juice content (JC) was estimated with the equation $\mathrm{JC}=[($ juice mass/sample mass $) \times 100]$. Juice mass was obtained by the difference between sample weight and bagasse mass (peel, seeds, and other fragments retained in the sieve). Total soluble solids (TSS), expressed in ${ }^{\circ}$ Brix, were measured using a digital refractometer Palette PR-32 $\alpha$ (Atago Co., Ltd., Tokyo, Japan), with values corrected to $20^{\circ} \mathrm{C}$.

Titratable acidity (TA) was determined with a semiautomatic burette with $0.1 \mathrm{~mol} \mathrm{~L}^{-1} \mathrm{NaOH}$ solution (titrant) and a phenolphthalein indicator, with the results expressed in grams of citric acid per $100 \mathrm{~mL}$ of juice (\%), as described in the physicochemical methods for food analysis (Instituto Adolfo Lutz, 2008). The ratio was determined as the quotient between TSS and TA.

The content of vitamin $\mathrm{C}$ was estimated with the oxidation-reduction volumetric technique, using $0.002 \mathrm{~mol} \mathrm{~L}^{-1}$ potassium iodate $\left(\mathrm{KIO}_{3}\right)$ solution and $1 \%$ starch indicator solution (Zenebon et al., 2008) as the standard titrant. Vitamin $\mathrm{C}$ content was expressed in milligrams per $100 \mathrm{~mL}$ of juice. Industrial income (RI) (Auler et al., 2008) was estimated with the expression $\mathrm{RI}=660 / \mathrm{TI}$, in which $\mathrm{TI}$ is the technological index obtained as juice content $\mathrm{x}$ TSS $\mathrm{x} 40.8$ divided by 10.000, which is equivalent to the amount of SST in the juice $(\mathrm{kg})$ in an industrial standard box of citrus (40.8 $\mathrm{kg}$ ). Industrial juice yield (IY) was estimated with the equation IY $=660 /$ TI. Except for fruit yield, which was analyzed throughout the years using repeated measures analysis of variance (Anova), followed by Scott-Knott tests, the remaining data were subjected to one-way Anova, followed by Scott-Knott tests, at 5\% probability.

The effect of rootstocks was also assessed on the following three key pests of citrus in the studied region: the citrus rust mite, P. oleivora; the Texas citrus mite, $E$. banksi; and the spider mite, T. mexicanus. The number of adults of these pest mites was counted monthly, from June 2011 to February 2013; however, data from August and September 2011 were not included in the analyses. For $P$. oleivora, two randomly-chosen fruits were evaluated per plant, totaling six fruits per rootstock in each assessment, and the mites were counted in a $1-\mathrm{cm}^{2}$ area. Only fruit located in the external part of the plant were taken, since this region is the most attacked by P. oleivora (Mendonça \& Silva, 2009). The number of adults of E. banksi and T. mexicanus was recorded in four randomly-collected leaves per tree, totaling 12 leaves per rootstock in each evaluation. Repeated measures Anova, followed by post-hoc Fisher tests, was conducted to assess the effect of rootstocks on the number of $P$. oleivora, E. banksi, and T. mexicanus, removing variance explained by time, as evaluations were carried out monthly.

\section{Results and Discussion}

The dry season in the Northeastern region of Brazil lasts from November to March (Souza et al., 2008), and the studied rootstocks affected the drought tolerance of 'Piemonte' mandarin (Figure 1). For instance, when grafted on the LVK x LCR-010 hybrid and on 'Santa 
Cruz Rangpur' lime, it showed the highest tolerance to drought, contrasting with the results for the combinations with 'Orlando' tangelo, 'Swingle' citrumelo, and 'San Diego' citrandarin, which showed symptoms such as leaf wilting, yellowing, and shriveling, as well as a slight drop of old leaves. Water deficiency symptoms in citrus are commonly observed in the coastal region of the states of Bahia and Sergipe (Souza et al., 2008), even when using the rootstock 'Rangpur' lime, which is known to induce tolerance to drought in a wide range of scion cultivars (Donato et al., 2007; Cunha Sobrinho et al., 2013).

Citrus trees subjected to water stress have virtually all aspects of growth and development affected, which could result in changes in their anatomy and morphology (Soares et al., 2015). The 'Santa Cruz Rangpur' lime is a natural bud mutant selected by Embrapa Mandioca e Fruticultura; however, there is little information about its effect on scion cultivars (Pompeu Junior \& Blumer, 2006). Seedlings of 'Star Ruby' grapefruit (C. paradisi) and acid lime clones of 'Tahiti CNPMF-01' [C. latifolia (Yu. Tanaka) Tanaka], when grafted on 'Santa Cruz Rangpur' lime, showed adequate scion development under conditions of water stress in a greenhouse (Soares et al., 2015). Nunes et al. (2006) found high rates -

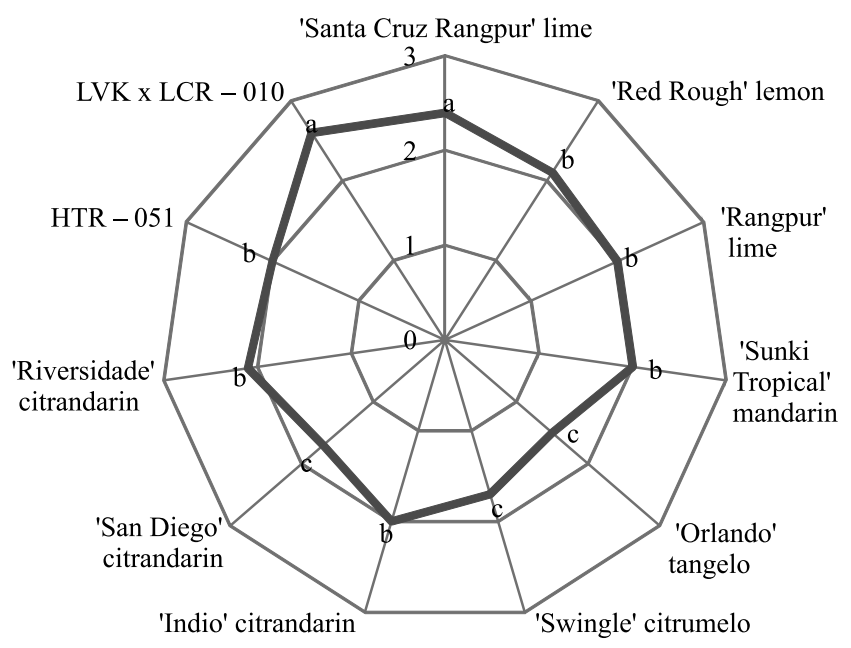

Figure 1. Means for drought tolerance (DT) of 'Piemonte' mandarin grafted on different rootstocks in the Brazilian Coastal Tablelands, from December to April 20112014. Equal letters indicate that DT means do not differ significantly by Scott-Knott tests, at $5 \%$ probability. DT values ranged from: 1 , susceptible to drought; to 3 , tolerant to drought. above $60 \%$ - of mycorrhizal colonization (FMA) in the LVK $x$ LCR-010 hybrid, showing that the interaction of the rootstock with FMA may be important for the adaptation of the plant to biotic and abiotic stresses. It is noteworthy that 'Rangpur' lime stands out for its production, agronomical characteristics, and drought tolerance (Pompeu Junior \& Blumer, 2011; Cunha Sobrinho et al., 2013). Cunha Sobrinho et al. (2013) also reported that 'Sunki Tropical' mandarin has good drought tolerance, which is in alignment with the results presented here. Prudente et al. (2004) observed that 'Rough' lemon suffers greater stress during periods of drought or increased demand for water, compared with 'Rangpur' lime, in the region of the Coastal Tablelands of the state of Sergipe.

'Red Rough' lemon, 'Rangpur' lime, 'Orlando' tangelo, and 'Swingle' citrumelo had the highest diameters below the grafting line (rootstock diameter), and, among them, the first and the second ones had the highest diameters above the grafting line (scion diameter) (Table 1). 'Fremont' mandarin ['Clementine' mandarin x 'Ponkan' mandarin (C. reticulata)], grown in the state of São Paulo, had a higher trunk diameter when grafted on 'Orlando' tangelo, in comparison with 'Rangpur' lime and 'Swingle' citrumelo as rootstocks (Núñez et al., 2007). Stuchi et al. (2008) evaluated the combination of some scion mandarins and rootstocks also in the state of São Paulo and observed that 'Swingle' citrumelo reduced the size of most scion cultivars and could be indicated for high-density orchards; conversely, 'Orlando' tangelo induced the formation of large-sized trees. Tazima et al. (2013) found that 'Okitsu' Satsuma mandarin [C. unshiu (Swingle) Marcow.] on 'Swingle' citrumelo had the largest rootstock trunk diameter, leading to the greatest difference between the RDBDA.

The difference between trunk diameters in scion and rootstock combinations may be an indicative of incompatibility (Stenzel et al., 2005; Tazima et al., 2013). Regarding the relationship between rootstock and scion cultivars, 'Piemonte' mandarin grafted on 'Swingle' citrumelo had the highest RDBDA value. The expected gain in performance of the scion cultivar is a function of the rootstock and of the affinity of both tissues (Schäfer et al., 2001). Although the obtained results do not show incompatibility issues, they may reflect the canopy development trend (Stenzel et al., 2005; Lima et al., 2014), highlighting the need for studies on symptoms of incompatibility (Pompeu Junior \& Blumer, 2009).

Pesq. agropec. bras., Brasília, v.51, n.11, p.1830-1838, nov. 2016 DOI: 10.1590/S0100-204X2016001100005 
Regarding plant height, 'Piemonte' mandarin grew higher in combination with common 'Rangpur' lime than when grafted on the remaining rootstocks. In contrast, it achieved small heights when grafted on 'Swingle' citrumelo. According to Auler et al. (2008), the vigor of the scion cultivar is directly affected by the rootstock. Tree size is important for planning new orchards because, with small trees, there is a possibility of increasing planting density per area, enabling the producer to have a faster return of the investment.

The largest canopy volumes of 'Piemonte' mandarin were obtained with 'Red Rough' lemon, common 'Rangpur' lime, 'Santa Cruz Rangpur' lime, and 'Sunki Tropical' mandarin as rootstocks, whereas the smallest canopy volumes were obtained with HTR-051 and 'Swingle' citrumelo as rootstocks, followed by the 'Indio' and 'San Diego' citrandarins. This shows that these rootstocks can be used to increase 'Piemonte' mandarin plant density in orchards.

Small tree size is a desirable feature for facilitating the implementation of management practices and harvest, besides allowing increasing planting density for greater productive efficiency (Silva et al., 2013; Lima et al., 2014). It should be pointed out that the citrandarins are hybrids of mandarins with trifoliate orange ( $P$. trifoliata) that have tolerance to diseases and form small-sized trees
(Pompeu Junior \& Blumer, 2011). 'Swingle' citrumelo reduced the size of most scion cultivars, indicating the possibility of its use in increasing plant density (Stuchi et al., 2008). Conversely, 'Orlando' tangelo induced large-sized scion canopies (Stuchi et al., 2008).

The combinations with 'Santa Cruz Rangpur' lime, 'Red Rough' lemon, and 'Riverside' citrandarin exceeded $70 \mathrm{Mg} \mathrm{ha}^{-1}$ of the accumulated yield (Table 1). 'Piemonte' mandarin grafted on LVK x LCR-010, 'Sunki Tropical' mandarin, common 'Rangpur' lime, and the 'Indio' and 'San Diego' citrandarins also had high cumulative yields of 68.4, 69.1, 61.2, 57.6, and 55.1 $\mathrm{Mg} \mathrm{ha}^{-1}$, respectively.

For most of the rootstocks, higher yields of 'Piemonte' mandarin were attained in 2013 (Table 1). These results agree with others showing 'Piemonte' mandarin, along with others scion cultivars, as new alternatives to orchard varietal diversification in Northeastern Brazil (Caputo et al., 2012; Cunha Sobrinho, et al., 2013; Passos et al., 2013). Cunha Sobrinho et al. (2013) reported that the 'Indio' and 'Riverside' citrandarin rootstocks promote more production and vigor than common 'Rangpur' lime grafted on orange trees. Regarding productive efficiency, the following rootstocks stood out: the 'Indio' and 'San Diego' citrandarins, HTR-051, and 'Swingle' citrumelo. The small size and high productive efficiency of 'Piemonte' mandarin grafted on these rootstocks show

Table 1. Trunk diameter of the evaluated rootstock (DA) and scion (DB) cultivars, relationship between the trunk diameter of the rootstock and scion below and above the grafting line (RDBDA), as well as plant height (PH), canopy volume, annual and cumulative yields (CY), and yield efficiency (YE) of 'Piemonte' mandarin, planted in the Brazilian Coastal Tablelands, during four harvest years, from 2011-2014 ${ }^{(1)}$.

\begin{tabular}{|c|c|c|c|c|c|c|c|c|c|c|c|}
\hline \multirow[t]{2}{*}{ Rootstock cultivar } & $\mathrm{DA}$ & DB & \multirow[t]{2}{*}{ RDBDA } & \multirow{2}{*}{$\begin{array}{l}\mathrm{PH} \\
(\mathrm{m})\end{array}$} & \multirow{2}{*}{$\begin{array}{c}\text { Canopy } \\
\text { volume }\left(\mathrm{m}^{3}\right)\end{array}$} & \multicolumn{5}{|c|}{ Yield $\left(\mathrm{kg} \mathrm{ha}^{-1}\right)^{(2)}$} & \multirow{2}{*}{$\begin{array}{c}\mathrm{YE} \\
\left(\mathrm{kg} \mathrm{m}^{-3}\right)\end{array}$} \\
\hline & \multicolumn{2}{|c|}{-------(cm)------- } & & & & 2011 & 2012 & 2013 & 2014 & $\mathrm{CY}$ & \\
\hline Santa Cruz Rangpur lime & $87.53 b$ & $76.67 \mathrm{~b}$ & $1.15 \mathrm{c}$ & $2.28 \mathrm{~b}$ & $8.35 \mathrm{a}$ & $16,625 \mathrm{bBC}$ & $15,775 \mathrm{bC}$ & $22,603 \mathrm{bA}$ & $18,983 \mathrm{bB}$ & $73,986 \mathrm{a}$ & $6.5 b$ \\
\hline Red Rough lemon & $94.02 \mathrm{a}$ & $85.40 \mathrm{a}$ & $1.11 \mathrm{c}$ & $2.30 \mathrm{~b}$ & $9.17 \mathrm{a}$ & $18,913 \mathrm{aB}$ & $12,576 \mathrm{cC}$ & $23,173 \mathrm{bA}$ & $18,630 \mathrm{cB}$ & $73,292 \mathrm{a}$ & $5.1 \mathrm{c}$ \\
\hline Common Rangpur lime & $91.49 \mathrm{a}$ & $82.94 \mathrm{a}$ & $1.10 \mathrm{c}$ & $2.45 \mathrm{a}$ & $8.73 \mathrm{a}$ & $13,567 \mathrm{~dB}$ & $9,428 \mathrm{fC}$ & $22,875 \mathrm{bA}$ & $15,415 \mathrm{gB}$ & $61,285 d$ & $6.3 b$ \\
\hline Sunki Tropical mandarin & $89.09 b$ & $77.93 b$ & $1.15 \mathrm{c}$ & $2.14 \mathrm{c}$ & $7.71 \mathrm{a}$ & $18,765 \mathrm{aA}$ & $17,087 \mathrm{aA}$ & $19,803 \mathrm{cA}$ & $13,530 \mathrm{hB}$ & $69,186 \mathrm{c}$ & $5.5 b$ \\
\hline Orlando tangelo & $92.30 \mathrm{a}$ & $76.55 b$ & $1.20 \mathrm{~b}$ & $2.10 \mathrm{c}$ & $6.44 b$ & $10,667 \mathrm{fBC}$ & $7,491 \mathrm{hC}$ & $16,103 \mathrm{eA}$ & $11,530 \mathrm{jB}$ & $45,792 \mathrm{~g}$ & $5.8 \mathrm{~b}$ \\
\hline Swingle citrumelo & $93.80 \mathrm{a}$ & $60.74 d$ & $1.59 \mathrm{a}$ & $1.76 \mathrm{e}$ & $3.61 \mathrm{~d}$ & $6,904 \mathrm{hC}$ & $6,824 \mathrm{iC}$ & $18,473 \mathrm{dA}$ & $12,496 \mathrm{iB}$ & $44,698 \mathrm{~h}$ & $7.2 \mathrm{a}$ \\
\hline Indio citrandarin & $70.07 \mathrm{~d}$ & $61.56 \mathrm{~d}$ & $1.15 \mathrm{c}$ & $1.90 \mathrm{~d}$ & $8.35 \mathrm{a}$ & $12,947 \mathrm{eBC}$ & $10,765 \mathrm{dC}$ & $18,043 \mathrm{dA}$ & $15,889 \mathrm{fAB}$ & $57,645 \mathrm{e}$ & $7.7 \mathrm{a}$ \\
\hline San Diego citrandarin & $83.51 b$ & $70.76 \mathrm{c}$ & $1.19 \mathrm{~b}$ & $1.97 \mathrm{~d}$ & $5.68 \mathrm{c}$ & $14,838 \mathrm{cB}$ & $9,957 \mathrm{eC}$ & $12,200 \mathrm{gBC}$ & $18,137 \mathrm{dA}$ & $55,132 f$ & $7.2 \mathrm{a}$ \\
\hline Riverside citrandarin & $88.23 b$ & $75.03 \mathrm{~b}$ & $1.18 \mathrm{~b}$ & $2.10 \mathrm{c}$ & $5.14 \mathrm{c}$ & $16,642 \mathrm{bB}$ & $15,310 \mathrm{bB}$ & $23,220 \mathrm{bA}$ & $16,665 \mathrm{eB}$ & $71,837 b$ & $6.4 \mathrm{~b}$ \\
\hline HTR-051 & 78.91c & $64.91 d$ & $1.21 \mathrm{~b}$ & $1.90 \mathrm{~d}$ & $3.94 \mathrm{~d}$ & $5,887 \mathrm{iB}$ & $8,008 \mathrm{gB}$ & $14,407 \mathrm{fA}$ & $11,757 \mathrm{jA}$ & $40,059 \mathrm{i}$ & $7.7 \mathrm{a}$ \\
\hline LVK x LCR-010 & $84.41 b$ & $77.15 b$ & $1.10 \mathrm{c}$ & $2.26 \mathrm{~b}$ & $6.47 b$ & $8,946 \mathrm{gC}$ & $11,140 \mathrm{dC}$ & $29,013 \mathrm{aA}$ & $19,385 \mathrm{aB}$ & $68,484 \mathrm{c}$ & $6.1 \mathrm{~b}$ \\
\hline Means & - & - & - & - & - & $13,155 \mathrm{C}$ & $11,306 \mathrm{D}$ & $19,992 \mathrm{~A}$ & $15,674 \mathrm{~B}$ & - & - \\
\hline CV (\%) Plot & 9.7 & 9.2 & 7.6 & 6.8 & 21.0 & 11.3 & 11.3 & 11.3 & 11.3 & 5.7 & 15.2 \\
\hline CV (\%) Split-plot & - & - & - & - & - & 10.9 & 10.9 & 10.9 & 10.9 & - & - \\
\hline
\end{tabular}

${ }^{(1)}$ Rootstock means followed by equal letters, lowercase in the columns and uppercase in the rows, do not differ by repeated measures analysis of variance (Anova) and by Scott-Knott tests, at 5\% probability. ${ }^{(2)}$ Year means followed by equal letters, uppercase in the rows, do not differ by repeated measures Anova and Tukey tests, at 5\% probability. CV, coefficient of variation. 
the potential of these materials for increasing planting density in orchards.

The productive efficiency characterized by the mass of fruits per canopy volume also reflects the need for small trees, enabling greater productivity per acreage (Cantuarias-Avilés et al., 2011, 2012). As previously mentioned, reducing the size of the plant is an important feature for easing management and cultivation (Lima et al., 2014). Therefore, it is evident that, with the same growing conditions, the productive performance of 'Piemonte' mandarin is a function of the combination between scion and rootstock.

Regarding the physicochemical quality of the fruit, significant differences were observed only in 2014 (Table 2). Fruit diameter and peel thickness were only affected by 'San Diego' citrandarin and the LVK $\mathrm{x}$ LCR-010 hybrid. Regarding TSS, the highest values were obtained with the HTR-051, 'Swingle' citrumelo, 'Orlando' tangelo, 'Rangpur' lime, 'Sunki Tropical' mandarin, and the 'Riverside', 'Indio', and 'San Diego' citrandarin rootstocks. Mandarins with high TSS contents are considered of better quality (CantuariasAvilés et al., 2010; Silva et al., 2013). As for TA, three categories were observed: high total titratable acidity (TTA) levels, from 0.75 to $0.78 \%$, for 'Rangpur' lime, 'Swingle' citrumelo, and the 'San Diego', 'Indio', and 'Riverside' citrandarins; low TTA levels, of 0.6 and $0.55 \%$ for 'Santa Cruz Rangpur' lime and 'Red rough' lemon, respectively; and intermediate TTA levels, from 0.68 to $0.72 \%$ for the remaining rootstocks. The lowest juice percentages were obtained with common 'Rangpur' lime, 'Santa Cruz Rangpur' lime, 'Red Rough' lemon, and LVK x LCR-010. The juice yields obtained here were higher than those described in other studies (Silva et al., 2009, 2013; Tazima et al., 2013), even accounting for differences among rootstocks. Regarding the TI, the same rootstocks that showed the highest TSS contents had the highest TI values, except common 'Rangpur' lime, which did not differ from those with lower TI. Mandarins, when grafted on 'Rough' lemon and

Table 2. Diameter, height, skin thickness, total soluble solids (TSS), titratable acidity (TA), vitamin C content, TSS/TA ratio, juice content (JC), and technological index (TI) of 'Piemonte' mandarin fruit grafted on different rootstocks in the Brazilian Coastal Tablelands, in the 2014 and 2015 harvests ${ }^{(1)}$.

\begin{tabular}{|c|c|c|c|c|c|c|c|c|c|}
\hline Rootstock cultivar & $\begin{array}{l}\text { Diameter } \\
\text {------ }\end{array}$ & $\begin{array}{c}\text { Height } \\
---(\mathrm{mm})\end{array}$ & Skin thickness & $\begin{array}{c}\text { TSS } \\
\left({ }^{\circ} \text { Brix }\right)\end{array}$ & $\begin{array}{l}\text { TA } \\
(\%)\end{array}$ & $\begin{array}{c}\text { Vitamin C } \\
\left(\mathrm{mg} \mathrm{L}^{-1}\right)\end{array}$ & $\begin{array}{c}\text { TSS/TA } \\
\text { ratio }\end{array}$ & $\begin{array}{c}\mathrm{JC} \\
(\%)\end{array}$ & $\begin{array}{c}\text { TI (kg of TSS } \\
\text { per box })^{(2)}\end{array}$ \\
\hline & \multicolumn{9}{|c|}{2014 harvest } \\
\hline Santa Cruz Rangpur lime & $83.33 b$ & $71.67 \mathrm{a}$ & $2.38 \mathrm{~b}$ & $8.83 b$ & $0.60 \mathrm{c}$ & $42.77 \mathrm{a}$ & $14.89 \mathrm{a}$ & $50.00 \mathrm{~b}$ & $1.80 \mathrm{~b}$ \\
\hline Red Rough lemon & $81.67 b$ & $71.33 \mathrm{a}$ & $2.65 b$ & $8.63 b$ & $0.55 \mathrm{c}$ & $43.09 \mathrm{a}$ & $15.85 \mathrm{a}$ & $51.60 \mathrm{~b}$ & $1.82 \mathrm{~b}$ \\
\hline Common Rangpur lime & $83.33 b$ & $68.33 \mathrm{a}$ & $2.13 b$ & $10.20 \mathrm{a}$ & $0.77 \mathrm{a}$ & $41.79 \mathrm{a}$ & $13.44 \mathrm{a}$ & $48.33 b$ & $2.01 \mathrm{~b}$ \\
\hline Sunki Tropical mandarin & $81.00 \mathrm{~b}$ & $69.00 \mathrm{a}$ & $2.10 \mathrm{~b}$ & $9.97 \mathrm{a}$ & $0.70 \mathrm{~b}$ & $41.95 \mathrm{a}$ & $14.27 \mathrm{a}$ & $61.00 \mathrm{a}$ & $2.48 \mathrm{a}$ \\
\hline Orlando tangelo & $81.67 b$ & $69.33 \mathrm{a}$ & $2.49 \mathrm{~b}$ & $9.70 \mathrm{a}$ & $0.69 b$ & $38.31 \mathrm{a}$ & $14.13 \mathrm{a}$ & $58.00 \mathrm{a}$ & $2.30 \mathrm{a}$ \\
\hline Swingle citrumelo & $81.00 \mathrm{~b}$ & $70.67 \mathrm{a}$ & $2.15 b$ & $10.33 \mathrm{a}$ & $0.78 \mathrm{a}$ & $39.68 \mathrm{a}$ & $13.21 \mathrm{a}$ & $59.00 \mathrm{a}$ & $2.49 \mathrm{a}$ \\
\hline Indio citrandarin & $77.67 \mathrm{~b}$ & $72.67 \mathrm{a}$ & $2.31 b$ & $10.60 \mathrm{a}$ & $0.75 \mathrm{a}$ & $40.93 a$ & $14.14 \mathrm{a}$ & $56.13 \mathrm{a}$ & $2.43 a$ \\
\hline San Diego citrandarin & $94.67 \mathrm{a}$ & $72.00 \mathrm{a}$ & $2.10 \mathrm{~b}$ & $10.57 \mathrm{a}$ & $0.76 \mathrm{a}$ & $39.47 \mathrm{a}$ & $14.00 \mathrm{a}$ & $60.67 \mathrm{a}$ & $2.62 \mathrm{a}$ \\
\hline Riverside citrandarin & $81.33 b$ & $69.67 \mathrm{a}$ & $2.45 \mathrm{~b}$ & $10.70 \mathrm{a}$ & $0.75 \mathrm{a}$ & $40.08 \mathrm{a}$ & $14.27 \mathrm{a}$ & $57.33 \mathrm{a}$ & $2.50 \mathrm{a}$ \\
\hline HTR-051 & $85.00 \mathrm{~b}$ & $71.33 \mathrm{a}$ & $2.19 b$ & $10.90 \mathrm{a}$ & $0.72 b$ & $41.11 \mathrm{a}$ & $15.19 \mathrm{a}$ & $58.67 \mathrm{a}$ & $2.62 \mathrm{a}$ \\
\hline LVK x LCR-010 & $81.00 \mathrm{~b}$ & $70.00 \mathrm{a}$ & $3.49 \mathrm{a}$ & $9.03 \mathrm{~b}$ & $0.68 \mathrm{~b}$ & $46.60 \mathrm{a}$ & $13.40 \mathrm{a}$ & $51.00 \mathrm{~b}$ & $1.88 \mathrm{~b}$ \\
\hline \multirow[t]{2}{*}{ CV (\%) } & 3.6 & 3.2 & 19.0 & 5.6 & 5.9 & 6.0 & 8.2 & 4.6 & 9.2 \\
\hline & \multicolumn{9}{|c|}{2015 harvest } \\
\hline Santa Cruz Rangpur lime & $88.57 \mathrm{a}$ & $65.27 \mathrm{a}$ & $1.92 \mathrm{a}$ & $11.80 \mathrm{a}$ & $0.92 \mathrm{a}$ & $45.73 a$ & $15.83 \mathrm{a}$ & $55.71 \mathrm{a}$ & $2.20 \mathrm{a}$ \\
\hline Red Rough lemon & $87.71 \mathrm{a}$ & $66.16 \mathrm{a}$ & $2.01 \mathrm{a}$ & $10.60 \mathrm{a}$ & $0.90 \mathrm{a}$ & $46.26 \mathrm{a}$ & $15.13 \mathrm{a}$ & $54.53 a$ & $2.01 \mathrm{a}$ \\
\hline Common Rangpur lime & $82.02 \mathrm{a}$ & $66.38 \mathrm{a}$ & $2.67 \mathrm{a}$ & $11.27 \mathrm{a}$ & $0.72 \mathrm{a}$ & $46.44 a$ & $19.23 \mathrm{a}$ & $55.17 \mathrm{a}$ & $2.13 a$ \\
\hline Sunki Tropical mandarin & $86.79 \mathrm{a}$ & $65.13 \mathrm{a}$ & $1.96 \mathrm{a}$ & $11.63 \mathrm{a}$ & $0.91 \mathrm{a}$ & $51.99 \mathrm{a}$ & $15.83 \mathrm{a}$ & $52.66 \mathrm{a}$ & $2.45 \mathrm{a}$ \\
\hline Orlando tangelo & $85.05 \mathrm{a}$ & $64.20 \mathrm{a}$ & $1.92 \mathrm{a}$ & $11.70 \mathrm{a}$ & $0.92 \mathrm{a}$ & $47.43 a$ & $13.33 \mathrm{a}$ & $56.51 \mathrm{a}$ & $2.23 \mathrm{a}$ \\
\hline Swingle citrumelo & $87.62 \mathrm{a}$ & $64.17 \mathrm{a}$ & $1.90 \mathrm{a}$ & $11.50 \mathrm{a}$ & $0.90 \mathrm{a}$ & $47.46 \mathrm{a}$ & $14.80 \mathrm{a}$ & $59.00 \mathrm{a}$ & $2.21 \mathrm{a}$ \\
\hline Indio citrandarin & $91.55 \mathrm{a}$ & $65.89 \mathrm{a}$ & $2.04 \mathrm{a}$ & $11.70 \mathrm{a}$ & $0.93 \mathrm{a}$ & $47.28 \mathrm{a}$ & $15.03 \mathrm{a}$ & $57.40 \mathrm{a}$ & $2.29 \mathrm{a}$ \\
\hline San Diego citrandarin & $91.53 \mathrm{a}$ & $67.95 \mathrm{a}$ & $2.03 \mathrm{a}$ & $11.63 \mathrm{a}$ & $0.91 \mathrm{a}$ & $44.57 \mathrm{a}$ & $15.43 \mathrm{a}$ & $56,61 \mathrm{a}$ & $2.10 \mathrm{a}$ \\
\hline Riverside citrandarin & $84.65 \mathrm{a}$ & $63.20 \mathrm{a}$ & $1.64 \mathrm{a}$ & $12.13 \mathrm{a}$ & $0.90 \mathrm{a}$ & $48.02 \mathrm{a}$ & $14.53 \mathrm{a}$ & $57.98 \mathrm{a}$ & $2.38 \mathrm{a}$ \\
\hline HTR-051 & $87.49 \mathrm{a}$ & $65.67 \mathrm{a}$ & $2.06 \mathrm{a}$ & $11.70 \mathrm{a}$ & $0.92 \mathrm{a}$ & $47.80 \mathrm{a}$ & $15.63 \mathrm{a}$ & $56.35 \mathrm{a}$ & $2.32 \mathrm{a}$ \\
\hline LVK x LCR-010 & $88.18 \mathrm{a}$ & $66.05 \mathrm{a}$ & $2.52 \mathrm{a}$ & $11.20 \mathrm{a}$ & $0.87 \mathrm{a}$ & $45.41 \mathrm{a}$ & $16.87 \mathrm{a}$ & $53.50 \mathrm{a}$ & $2.05 \mathrm{a}$ \\
\hline CV $(\%)$ & 3.6 & 3.0 & 17.3 & 3.9 & 9.0 & 7.5 & 10.14 & 4.6 & 10.3 \\
\hline
\end{tabular}

${ }^{(1)}$ Means followed by equal letters, in the columns, do not differ significantly by Scott-Knott tests, at $5 \%$ probability. ${ }^{(2)} \mathrm{kg}$ of TSS per box is of $40,8 \mathrm{~kg}$. $\mathrm{CV}$, coefficient of variation. 
'Rangpur' lime, tended to produce low-quality fruits, characterized by low contents of TSS, TA, and TI.

Regarding phytotechnical constraints, plant resistance to pests is one of several strategies of integrated management programs (Gallo et al., 2002; Chacón et al., 2012), contributing to keep pest infestations below economic levels (Gallo et al., 2002; Vendramim \& Guzzo, 2012). However, the obtained results showed that the rootstocks did not affect the population levels of the evaluated pest mites (Figure 2): P. oleivora $\left(\mathrm{F}_{10,22}\right.$ $=0.999 ; \mathrm{P}=0.473)$, E. banksi $\left(\mathrm{F}_{10,22}=0.747 ; \mathrm{P}=0.674\right)$, and T. mexicanus $\left(\mathrm{F}_{10,22}=0.985 ; \mathrm{P}=0.483\right)$. These results contrast with those of Silva et al. (2016), who reported that natural infestations of P. oleivora and T. mexicanus on the 'Pêra' and 'Valência Tuxpan' sweet oranges were affected by the analyzed rootstocks, in some periods of the year, in the state of Sergipe. These results indicate the effect of some genotypes on the population densities of these pests. Moreover, Andrade et al. (2013) showed that the number of the leprosis mite, B. phoenicis, on 'Pêra' sweet orange was also affected by rootstocks, in the state of São Paulo; where lower population levels of B. phoenicis were found on 'Pêra' sweet orange grafted on 'Sunki' mandarin, in comparison with 'Cleopatra' mandarin and 'Rangpur' lime.

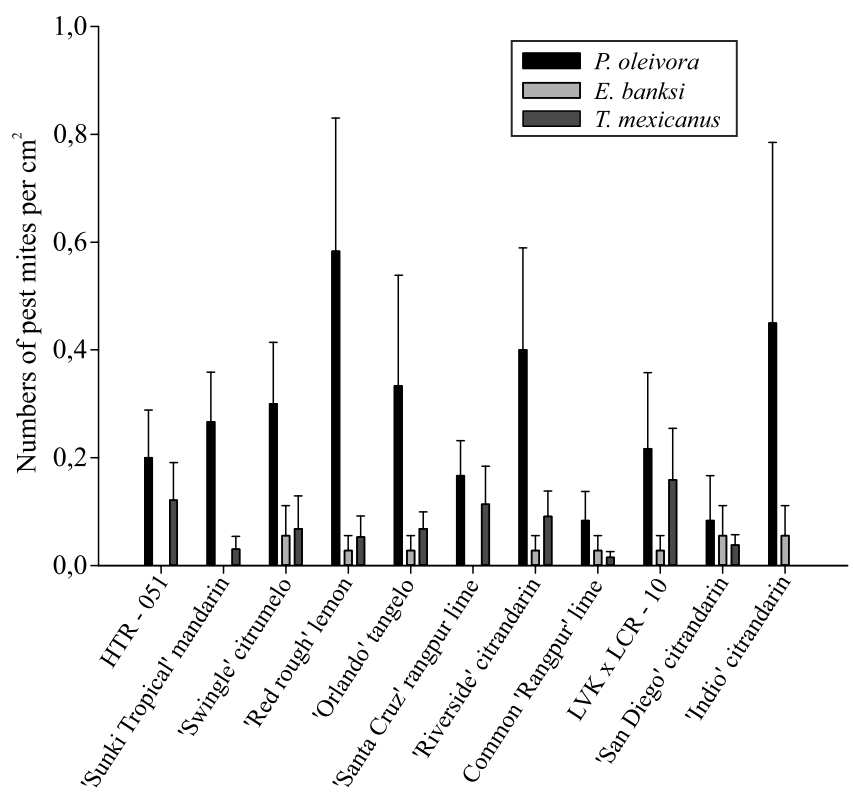

Figure 2. Population levels of the pest mites Phyllocoptruta oleivora, on fruits, and Eutetranychus banksi and Tetranychus mexicanus, on leaves, on 'Piemonte' mandarin grafted on different rootstocks in the Brazilian Coastal Tablelands. Vertical bars represent means + standard error.

\section{Conclusions}

1. The common 'Rangpur' lime, 'Santa Cruz Rangpur' lime, 'Red Rough' lemon, and 'Sunki Tropical' mandarin rootstocks provide more vigorous plants, whereas common 'Rangpur' lime, 'Santa Cruz Rangpur' lime, and the LVK x LCR-010 hybrid confer great drought tolerance to 'Piemonte' mandarin.

2. 'Piemonte' mandarin grafted on 'Santa Cruz Rangpur' lime, 'Red Rough' lemon, 'Sunki Tropical' mandarin, and 'Riverside' citrandarin shows good production performance.

3. The low size and high yield efficiency of 'Piemonte' mandarin on the 'Indio' and 'San Diego' citrandarins, HTR-051 hybrid, and 'Swingle' citrumelo rootstocks show their potential for high-density plantings.

4. The evaluated rootstocks do not affect the population levels of the pest mites Phyllocoptruta oleivora, Eutetranychus banksi, and Tetranychus mexicanus on 'Piemonte' mandarin.

\section{Acknowledgments}

To Inácio de Barros, for helping with the statistical yield analysis.

\section{References}

ALMEIDA, C.O. de; PASSOS, O.S. (Ed.). Citricultura brasileira em busca de novos rumos: desafios e oportunidades na região Nordeste. Cruz das Almas: Embrapa Mandioca e Fruticultura, 2011.160p.

ANDRADE, D.J.; FALCONI, R.S.; SIQUEIRA, D.S.; BARBOSA, C.L.; FERRAUDO, A.S.; OLIVEIRA, C.A.L. The influence of citrus rootstocks on the relationship between the mite Brevipalpus phoenicis and citrus leprosis disease. Pest Management Science, v.69, p.81-87, 2013. DOI: 10.1002/ps.3365.

AULER, P.A.M.; FIORI-TUTIDA, A.C.G.; TAZIMA, Z.H. Comportamento da laranjeira 'Valência' sobre seis porta-enxertos no noroeste do Paraná. Revista Brasileira de Fruticultura, v.30, p.229-234, 2008. DOI: 10.1590/S0100-29452008000100042.

BASTOS, D.C.; FERREIRA, E.A.; PASSOS, O.S.; SÁ, J.F. de; ATAÍDE, E.M.; CALGARO, M. Cultivares copa e porta-enxertos para a citricultura brasileira. Informe Agropecuário, v.35, p.36$45,2014$.

CANTUARIAS-AVILÉS, T.; MOURÃO FILHO, F. de A.A.; STUCHI, E.S.; SILVA, S.R. da; ESPINOZA-NÚÑEZ, E. Tree performance and fruit yield and quality of 'Okitsu' Satsuma mandarin grafted on 12 rootstocks. Scientia Horticulturae, v.123, p.318-322, 2010. DOI: 10.1016/j.scienta.2009.09.020.

CANTUARIAS-AVILÉS, T.; MOURÃO FILHO, F. de A.A.; STUCHI, E.S.; SILVA, S.R. da; ESPINOZA-NUÑES, E. 
Horticultural performance of 'Folha Murcha' sweet orange onto twelve rootstocks. Scientia Horticulturae, v.129, p.259-265, 2011. DOI: 10.1016/j.scienta.2011.03.039.

CANTUARIAS-AVILÉS, T.; MOURÃO FILHO, F. de A.A.; STUCHI, E.S.; SILVA, S.R. da; ESPINOZA-NÚÑES, E.; BREMER NETO, H. Rootstocks for high fruit yield and quality of 'Tahiti' lime under rain-fed conditions. Scientia Horticulturae, v.142, p.105-111, 2012. DOI: 10.1016/j.scienta.2012.05.008.

CAPUTO, M.M.; MOURÃO FILHO, F. de A.A.; SILVA, S.R. da; BREMER NETO, H.; COUTO, H.T.Z. do; STUCHI, E.S. Seleção de cultivares de laranja doce de maturação precoce por índices de desempenho. Pesquisa Agropecuária Brasileira, v.47, p.16691672, 2012. DOI: 10.1590/S0100-204X2012001100015.

CHACÓN, J.M.; ASPLEN, M.K.; HEIMPEL, G.E. Combined effects of host-plant resistance and intraguild predation on the soybean aphid parasitoid Binodoxys communis in the field. Biological Control, v.60, p.16-25, 2012. DOI: 10.1016/j. biocontrol.2011.09.003.

CINTRA, F.L.D.; RESENDE, R.S.; LEAL, M. de L. da S.; PORTELA, J.C. Efeito de volumes de água de irrigação no regime hídrico de solo coeso dos tabuleiros e na produção de coqueiro. Revista Brasileira de Ciência do Solo, v.33, p.1041-1051, 2009. DOI: $10.1590 /$ S0100-06832009000400028.

CUNHA SOBRINHO, A.P. da; PASSOS, O.S.; SOARES FILHO, W. dos S. Cultivares porta-enxerto. In: CUNHA SOBRINHO, A.P. da; MAGALHÃES, A.F. de J.; SOUZA, A. da S.; PASSOS, O.S.; SOARES FILHO, W. dos S. Cultura dos citros. Brasília: Embrapa, 2013. v.1, p.233-292.

DONATO, S.L.R.; PEREIRA, C.S.; BARROS, Z. de J.; SIQUEIRA, D.L. de; SALOMÃO, L.C.C. Respostas de combinações de variedades copa e porta-enxerto de citros à deficiência hídrica. Pesquisa Agropecuária Brasileira, v.42, p.1507-1510, 2007. DOI: 10.1590/S0100-204X2007001000020.

FAO. Food and Agriculture Organization. Faostat. Available at: $<$ http://faostat3.fao.org/faostat>. Accessed on: Mar. 132015.

GALLO, D.; NAKANO, O.; SILVEIRA NETO, S.; CARVALHO, R.P.L.; BAPTISTA, G.C. de; BERTI FILHO, E.; PARRA, J.R.P.; ZUCCHI, R.A.; ALVES, S.B.; VENDRAMIM, J.D.; MARCHINI, L.C.; LOPES, J.R.S.; OMOTO, C. Entomologia agrícola. Piracicaba: Fealq, 2002. 920p.

LIMA, C.F. de; MARINHO, C.S.; COSTA, E.S.; ALMEIDA, T.R. de V. e; AMARAL, C.O. Qualidade dos frutos e eficiência produtiva da laranjeira 'Lima' enxertada sobre 'Trifoliata', em cultivo irrigado. Revista Brasileira de Ciências Agrárias, v.9, p.401-405, 2014. DOI: 10.5039/agraria.v9i3a4433.

MARTINS, C.R.; CARVALHO, H.W.L.; TEODORO, A.V.; SOARES FILHO, W.S.; PASSOS, O.S. Agronomical performance of citrus scion cultivars grafted on Rangpur lime in north-eastern Brazil. Australian Journal of Crop Science, v.10, p.16-23, 2016.

MARTINS, C.R.; TEODORO, A.V.; CARVALHO, H.W.L. de. Citricultura no Estado de Sergipe. Citricultura Atual, v.17, p.1417, 2014.

MENDONÇA, M.C.; SILVA, L.M.S. Pragas dos citros. In: SILVA, L.M. da; MENDONÇA, M. da C. (Ed.). Manual do manejador fitossanitário dos citros. Aracaju: Embrapa Tabuleiros Costeiros, 2009. p.19-41.

MORAES FILHO, R.M.; JIMENEZ, H.J.; MONTARROYOS, A.V.V.; MUSSER, R.S.; SILVA, M.M.; SILVA, E.F.; MARTINS, L.S.S. Variabilidade genética em genótipos da coleção de germoplasma de Citrus, do Instituto Agronômico de Pernambuco Brejão-PE, por meio de marcadores moleculares ISSR. Citrus Research and Technology, v.32, p.67-76, 2011.

MORAES, G.J. de; FLECHTMANN, C.H.W. Manual de acarologia: acarologia básica e ácaros de plantas cultivadas no Brasil. Ribeirão Preto: Holos, 2008. p.288.

NUNES, M. de S.; SOARES, A.C.F.; SOARES FILHO, W. dos S.; LEDO, C.A. da S. Colonização micorrízica natural de portaenxertos de citros em campo. Pesquisa Agropecuária Brasileira, v.41, p.525-528, 2006. DOI: 10.1590/S0100-204X2006000300021.

NÚÑEZ, E.E.; MOURÃO FILHO, F. de A.A.; STUCHI, E.S. Desenvolvimento vegetativo, produção e qualidade de frutos da tangerina 'Fremont' sobre quatro porta-enxertos. Revista Brasileira de Fruticultura, v.29, p.308-312, 2007. DOI: 10.1590/ S0100-29452007000200023.

PASSOS, O.S.; CUNHA SOBRINHO, A.P. da; SOARES FILHO, W. dos S. Cultivares copa. In: CUNHA SOBRINHO, A.P. da; MAGALHÃES, A.F. de J.; SOUZA, A. da S.; PASSOS, O.S.; SOARES FILHO, W. dos S. Cultura dos citros. Brasília: Embrapa, 2013. p.293-319.

POMPEU JUNIOR, J.; BLUMER, S. A introdução de germoplasma: uma contribuição ao melhoramento dos citros. Laranja, v.27, p.341-354, 2006.

POMPEU JUNIOR, J.; BLUMER, S. Citrandarins e outros híbridos de trifoliata como porta-enxertos para laranjeira Valência. Citrus Research and Technology, v.32, p.133-138, 2011.

POMPEU JUNIOR, J.; BLUMER, S. Híbridos de trifoliata como porta-enxertos para a laranjeira 'Valência'. Pesquisa Agropecuária Brasileira, v.44, p.701-705, 2009. DOI: 10.1590/ S0100-204X2009000700008.

PRUDENTE, R.M.; SILVA, L.M.S. da; CUNHA SOBRINHO, A.P. da. Comportamento da laranjeira 'Pêra' sobre cinco portaenxertos em ecossistema de tabuleiros costeiros, Umbaúba - SE. Revista Brasileira de Fruticultura, v.26, p.110-112, 2004. DOI: 10.1590/S0100-29452004000100030.

SCHÄFER, G.; BASTIANEL, M.; DORNELLES, A.L.C. Portaenxertos utilizados na citricultura. Ciência Rural, v.31, p.723-733, 2001. DOI: $10.1590 /$ S0103-84782001000400028.

SILVA, R.R. da; TEODORO, A.V.; VASCONCELOS, J.F.; MARTINS, C.R.; SOARES FILHO, W. dos S.; CARVALHO, H.W.L. de; GUZZO, E.C. Citrus rootstocks influence the population densities of pest mites. Ciência Rural, v.46, n.1, p.1-6, 2016. DOI: 10.1590/0103-8478cr20150486.

SILVA, S.R. da; OLIVEIRA, J.C. de; STUCHI, E.S.; REIFF, E.T. Qualidade e maturação de tangerinas e seus híbridos em São Paulo. Revista Brasileira de Fruticultura, v.31, p.977-986, 2009.

SILVA, S.R. da; STUCHI, E.S.; GIRARDI, E.A.; CANTUARIASAVILÉS, T.; BASSAN, M.M. Desempenho da tangerineira 'Span

Pesq. agropec. bras., Brasília, v.51, n.11, p.1830-1838, nov. 2016 DOI: $10.1590 / \mathrm{S} 0100-204 X 2016001100005$ 
Americana' em diferentes porta-enxertos. Revista Brasileira de Fruticultura, v.35, p.1052-1058, 2013.

SOARES, L.A. dos A.; BRITO, M.E.B.; FERNANDES, P.D.; LIMA, G.S. de; SOARES FILHO, W. dos S.; OLIVEIRA, E.S. de. Crescimento de combinações copa-porta-enxerto de citros sob estresse hídrico em casa de vegetação. Revista Brasileira de Engenharia Agrícola e Ambiental, v.19, p.211-217, 2015. DOI: 10.1590/1807-1929/agriambi.v19n3p211-217.

SOUZA, L. da S.; SOUZA, L.D.; PAIVA, A. de Q.; RODRIGUES, A.C.V.; RIBEIRO, L. da S. Distribuição do sistema radicular de citros em uma toposseqüência de solos de tabuleiro costeiro do Estado da Bahia. Revista Brasileira de Ciência do Solo, v.32, p.503-513, 2008. DOI: 10.1590/S0100-06832008000200005.

STENZEL, N.M.C.; NEVES, C.S.V.J.; MARUR, C.J.; GOMES, J.C. Crescimento vegetativo de plantas cítricas no norte e noroeste do Paraná. Revista Brasileira de Fruticultura, v.27, p.412-417, 2005. DOI: 10.1590/S0100-29452005000300018.

STUCHI, E.S.; DONADIO, L.C.; SEMPIONATO, O.R. Tolerância à seca da laranjeira 'Folha Murcha' em 10 porta-enxertos. Revista Brasileira de Fruticultura, v.22, p.454-457, 2000.

STUCHI, E.S.; ESPINOZA-NÚÑEZ, E.; MOURÃO FILHO, F. de A.A.; ORTEGA, E.M.M. Vigor, produtividade e qualidade de frutos de quatro tangerineiras e híbridos sobre quatro porta-enxertos. Revista Brasileira de Fruticultura, v.30, p.741-747, 2008.

TAZIMA, Z.H.; NEVES, C.S.V.J.; YADA, I.F.U.; LEITE JÚNIOR, R.P. Performance of 'Okitsu' Satsuma mandarin on nine rootstocks. Scientia Agricola, v.70, p.422-427, 2013.

TEODORO, A.V.; MENDONÇA, M. da C.; NASCIMENTO, A.S. do; SILVA, L.M.S. da; FARIAS, A.P. Características e medidas de controle das principais pragas dos citros, nos Estados da
Bahia e Sergipe. Aracaju: Embrapa Tabuleiros Costeiros, 2014. 8p. (Embrapa Tabuleiros Costeiros. Comunicado Técnico, 142).

VENDRAMIM, J.D.; GUZZO, E.C. Plant resistance and insect bioecology and nutrition. In: PANIZZI, A.R.; PARRA, J.R.P. (Ed.). Insect bioecology and nutrition for integrated pest management. Boca Raton: CRC Press; Brasília: Embrapa, 2012. p.657-685.

WU, G.A.; PROCHNIK, S.; JENKINS, J.; SALSE, J.; HELLSTEN, U.; MURAT, F.; PERRIER, X.; RUIZ, M.; SCALABRIN, S.; TEROL, J.; TAKITA, M.A.; LABADIE, K.; POULAIN, J.; COULOUX, A.; JABBARI, K.; CATTONARO, F.; DEL FABBRO, C.; PINOSIO, S.; ZUCCOLO, A.; CHAPMAN, J.; GRIMWOOD, J.; TADEO, F.R.; ESTORNELL, L.H.; MUÑOZSANZ, J.V.; IBANEZ, V.; HERRERO-ORTEGA, A.; ALEZA, P.; PÉREZ-PÉREZ, J.; RAMÓN, D.; BRUNEL, D.; LURO, F.; CHEN, C.; FARMERIE, W.G.; DESANY, B.; KODIRA, C.; MOHIUDDIN, M.; HARKINS, T.; FREDRIKSON, K.; BURNS, P.; LOMSADZE, A.; BORODOVSKY, M.; REFORGIATO, G.; FREITAS-ASTÚA, J.; QUETIER. F.; NAVARRO, L.; ROOSE, M.; WINCKER, P.; SCHMUTZ, J.; MORGANTE, M.; MACHADO, M.A.; TALON, M.; JAILLON, O.; OLLITRAULT, P.; GMITTER, F.; ROKHSAR, D. Sequencing of diverse mandarin, pummelo and orange genomes reveals complex history of admixture during citrus domestication. Nature Biotechnology, v.32, p.656-662, 2014.

ZENEBON, O.; PASCUET, N.S.; TIGLEA, P. (Coord.). Métodos físico-químicos para análise de alimentos. 4.ed. São Paulo: Instituto Adolfo Lutz, 2008. 1020p.

ZHANG, Y.; SUN, Y.; XI, W.; SHEN, Y.; QIAO, L.; ZHONG, L.; YE, X.; ZHOU, Z. Phenolic compositions and antioxidant capacities of Chinese wild mandarin (Citrus reticulata Blanco) fruits. Food Chemistry, v.145, p.674-680, 2014. DOI: 10.1016/j. foodchem.2013.08.012.

Received on August 11, 2015 and accepted on October 10, 2016 